\title{
All Consumers Are Same for the Effect of Brand Citizenship Behaviors?: The Role of Nationality
}

\author{
Ezgi Erkmen ${ }^{1}$ \\ ${ }^{1}$ School of Applied Sciences, Ozyegin University, Istanbul, Turkey \\ Correspondence: Ezgi Erkmen, School of Applied Sciences, Ozyegin University, Cekmekoy-Istanbul, Turkey. \\ Tel: 90-216-564-9594. E-mail: ezgi.erkmen@ozyegin.edu.tr
}

\author{
Received: March 31, 2014 Accepted: April 28, $2014 \quad$ Online Published: May 21, 2014 \\ doi:10.5539/ijms.v6n3p65 URL: http://dx.doi.org/10.5539/ijms.v6n3p65
}

\begin{abstract}
Managing brand related attitudes and behaviors of customer contact employees has gained importance for airline services recently. However, there is still need for further understanding of employees' brand related behaviors and their effect on consumers. Therefore, the purpose of this study is to understand the moderating role of consumer nationality on the link between employee brand behaviors and consumers' relation with the brand in terms of their trust and commitment in the airline industry. This study analyzed both service employees and consumers in the same research model to understand the effect of brand citizenship behaviors of employees on consumer brand relationship as well as the role of nationality on brand trust and commitment of consumers. The uniqueness of this study is to integration of nationality as a moderator into the link between employee behaviors and consumer brand relationship as well as using both employees and customers in the same research setting. While the results suggest that airline employees' brand related behaviors have a significant effect on passengers' trust, the relation is moderated by consumers' nationality. Specifically, the brand trust is higher for the passengers who are from the same nationality with the employees.
\end{abstract}

Keywords: brand citizenship behaviors, brand trust, brand commitment, nationality

\section{Introduction}

Solomon et al. (1985, p. 99) distinguished between marketing of services and marketing of products as "service marketing refers to marketing of activities and processes rather than objects". It is for this reason that marketing of services is a challenge compared to marketing of tangible goods (Grönroos, 1978; Zeithaml et al., 1985). Specifically for branding, it is about delivering the service promise through direct interaction between employees and consumers. As a result, branding of services also differs from branding of products due to its reliance on employees' behaviors to deliver the brand promise at each service encounter (de Chernatony \& Segal-Horn, 2001).

In service based industries, when consumers experience a service, they usually need to reevaluate the service in each distinct service encounter due to variable nature of services (Zeithaml et al., 1985). Each service encounter represents a distinct contact with consumers, and it depends on the performance of service employees. Therefore, the fulfillment of brand promise at each service contact relies on the consistent behaviors of employees during their consumer interaction. Particularly, the point is to consistently realize the brand promise at each service encounter and to establish trust toward the brand (Burmann \& Zeplin, 2005). As a result, branding is especially important for service industries because a strong brand helps to build trust for an intangible offering that is difficult to evaluate before actual purchase (Berry \& Lampo, 2004). Accordingly, brand helps a consumer to develop relationship with a service provider through trust in a service brand (de Chernatony \& Segal-Horn, 2001).

As in other service industries, building relationship with consumers for the long-term success of the companies is also important in the airline travel. The airline industry was the first to implement relationship marketing programs in order to enhance relations with their passengers (Kim et al., 2001). However, frequent flyer programs do not have their intended returns anymore due to similar programs applied by many airline companies. Therefore, companies started to look for new ways of establishing relationship with their passengers (Gilbert, 1996). With the recognition of the importance of service for increasing passenger satisfaction and for repurchase intention (Park et al., 2006), airline companies started to position their brand in the minds of consumers through 
their employees (Miles \& Mangold, 2005). The purpose is to develop trust and commitment by delivering a consistent brand promise through employees' behaviors at each service encounter.

However, even consistent behaviors of employees might explain the consumers' evaluation of brand and their relationship with the brand, other factors may affect the link between employee behaviors and consumers' attitudes toward a brand (Hill \& Tombs, 2011). One of the factors is the cultural congruency that leads consumers to have more favorable perceptions of service provider, which is similar in terms of cultural aspects (Alden et al., 2009). Although previous research has studied the relation between employees' brand supporting behaviors and consumers' relationship quality with a brand in the service industry (Burmann \& Zeplin, 2005; Burmann et al., 2009), no previous study has examined the effect of nationality on the relation between employee behaviors and consumers' evaluation of a brand. Therefore, the purpose of this study is to understand the moderating role of nationality on the link between employee brand citizenship behaviors and consumers' relation with the brand in terms their trust and commitment toward a brand in airline industry.

As a result, this study contributed to the previous research on the effect of brand citizenship behaviors in different ways. First, previous studies have examined the effect of employees' brand citizenship behaviors from the perspective of management and employees. However, this study used both employee and customer data in the same research model in order to overcome the common variance problems due to same respondent providing the measure both for predictor and criterion variable. Second, even previous literature have studied brand citizenship behaviors of airline employees (Miles \& Mangold, 2005), limited attention has been given to empirically analyze these behaviors in the airline industry. Thus, this study has extended the research on the effect of employee brand citizenship behaviors by providing empirical support for airline travel.

\section{Review of Literature}

\subsection{Employees' Brand Citizenship Behaviors}

The service encounter highly depends on attitude and motivation of service employees to shape the brand image of consumers (Bowen et al., 1990). As a result, branding programs need to focus on employee behaviors and customer experience. This is because the success of a service brand, both internally and externally, depends on employees' attitudes and behaviors (Vella et al., 2009). Moreover, these employee behaviors affect the brand performance (Berthon et al., 2005). As in other service industries, employees also contribute to the branding efforts in airline travel. The behaviors and attitudes of employees are especially important due to their effect on employee-consumer interaction (Teng \& Barrows, 2009). Frost and Kumar (2001) have identified that airline employees have the opportunity to both negatively and positively affect the perceptions of airline service quality during their interaction with airline passengers. Therefore, involving employees in branding activities and aligning their behaviors with the brand promise are becoming a major issue for the success in travel industry.

With the increased attention on employees' role in branding, Burmann and Zeplin (2005) have first introduced the employee brand citizenship behaviors across organizational citizenship concept. Specifically, brand citizenship concept has proposed that employees are required to live the brand during their customer interaction and to align their behaviors with the brand. In other terms, the construct mainly refers to employee behaviors that enhance the delivery of brand promise by including external behaviors as well as intra-organizational behaviors. The idea is to enhance the service behaviors of employees during their interaction with consumers to transform the brand image into reality. As a result, employees' performance turns into brand experience for consumers and affects consumers' relationship with the brand as well.

\subsection{Brand Trust and Brand Commitment of Consumers}

Strong brands are the basis to establish relationship with consumers (Cleaver, 1999; Fournier, 1998). Although brands help to form relationship with consumers for both products and services, it is more challenging for services. This is because personal interaction is the key to create successful relationships (O'Loughlin et al., 2004). Therefore, employees have a considerable role in affecting relationships with the brand due to their consumer contact (Fournier, 1998). Furthermore, the interaction between consumers and employees is a determinant of quality of the relationship in services context because employees providing the service are perceived to be indifferent from the organization itself.

Specifically for the airline industry, employees were found to affect the perceptions for airline service quality during their interaction with airline passengers (Frost \& Kumar, 2001). This perceived quality usually evolves from a passenger's direct experience with the airline company, and it influences future purchases regarding that company (Chen \& Chang, 2008). Therefore, airline employees have a crucial role in building relationships with passengers. Even airline companies have started to offer frequent flyer programs to develop long-term 
relationships with passengers, consumers see no difference among airline companies based on these programs (Ott, 1993), and service is much more important to achieve differentiation (Ostrowski et al., 1993). Hence, it is reasonable to argue that branding might form the basis of relationship building in airline industry.

The reason why branding is especially important for service industries is that a strong brand helps consumers to build trust in an intangible offering that is difficult to evaluate before actual purchase (Berry \& Lampo, 2004). It might be difficult to understand the service promise due to the nature of services, but a consumer can evaluate a relationship arising from trust with a service brand (de Chernatony \& Segal-Horn, 2001). Particularly, trust is more related in situations where the uncertainty is high (Moorman et al., 1992). Therefore, trust might be more important for services because it is not only difficult to evaluate a service beforehand, but services also depend on employee performance.

Sirdeshmukh et al. (2002, p. 17) have defined consumer trust as "the expectations held by the consumer that the service provider is dependable and can be relied on to deliver its promises". As a result, brand trust of a consumer evolves through experience with the brand, and this experience might be based on satisfaction with the brand (Keller, 1993). Moreover, Morgan \& Hunt (1994) have proposed that trust is central to the idea of relationship marketing and results in commitment. Therefore, trust and commitment have been identified as two key constructs to explain why consumers establish relationships with companies (Dwyer et al.,1987; Morgan \& Hunt, 1994). Consumers would build trust and commitment to a brand, if the particular brand meets its brand promise. Hence, this study argues that better performance of the brand through brand citizenship behaviors of employees will affect the consumers' brand trust and their commitment. As a result, the following hypotheses are proposed:

H1: Brand citizenship behaviors of service employees will have a direct and positive effect on consumer brand trust.

H2: Brand citizenship behaviors of service employees will have a direct and positive effect on consumer brand commitment.

H3: Brand trust of customers will have a direct and positive effect on consumer brand commitment.

\subsection{Linking Employee Behaviors to Customers Relation with the Brand}

With the increased attention on interaction between service employees and consumers, previous research has studied the factors affecting customers' evaluation of services during a service encounter (Hennig-Thurau et al., 2006; Hill \& Tombs, 2011; Surprenant \& Michael, 1987). Many characteristics of customer contact employees, such as emotions, helpfulness, or demographics, were found to influence consumers' evaluation of services. Furthermore, cultural congruency was argued to have an important role in consumer service evaluations. More specifically, cultural congruency theory proposes that people favor the service providers having cultural similarities. When consumers perceive the service provider to be similar to them, they tend to have more confidence and to feel less perceived risk (Alden et al., 2009; Kogut \& Singh, 1988). Thus, consumers might have tendency to evaluate a service provider coming from the same nationality more positively as a result of perceived similarities.

Also for the airline travel, it has been found that nationality has a moderating effect on consumer behaviors. Pizam and Sussman (1995) have found that employees in the tourism industry tend to perceive customers differently based on their nationalities. Additionally, it has been found that national stereotyping also affects employees' service behaviors (Cuddy et al., 2007). In the airline industry, airline employees were found to serve passengers based on their cognition and emotions. Accordingly, they show better service behaviors towards passengers from their own nationality (Kim \& Lee, 2009). Therefore, given the importance of nationality in a service context, both customers and employees might perceive each other more favorably due to being from the same nation. Moreover, consumers may also have more confidence due to cultural bounds and similarities, thereby resulting in trust and commitment for the service provider. With the recognition of previous discussion, following hypotheses are proposed;

H4. Nationality of customers moderates the link between employee brand citizenship behaviors and customer brand trust.

H5. Nationality of customers moderates the link between employee brand citizenship behaviors and customer brand commitment.

Based on the theoretical foundations and proposed hypotheses, this study proposed a conceptual framework (see Figure 1), explaining how employees' brand citizenship behaviors and nationality affect consumers' relation with the brand. 


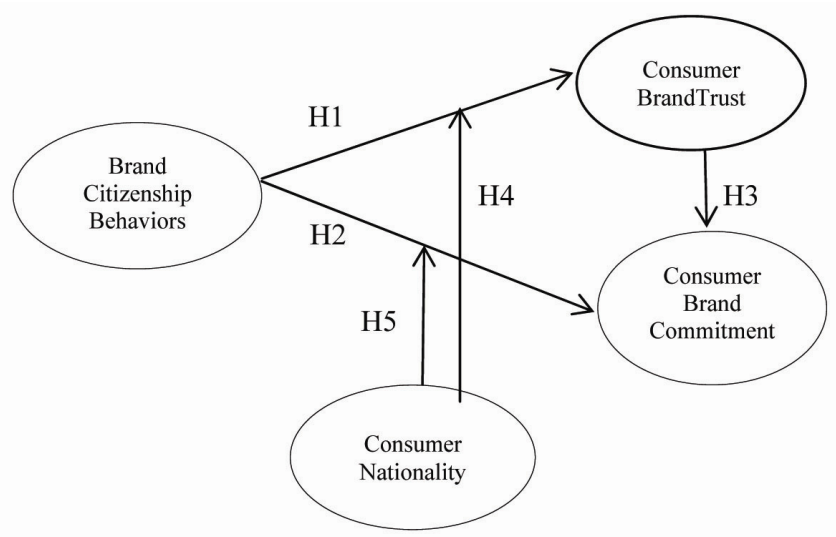

Figure 1. Conceptual framework for the study

\section{Methods}

\subsection{Data Collection}

This study applied conceptual integration of both employees and consumers to understand the effect of employees' brand citizenship behaviors on consumers' relation with the brand. The sample was initiated by contacting a corporate airline company in Turkey. To test the conceptual model, the current study mainly used both flight attendants and passengers of the respective airline company in the same research model.

A quantitative empirical causal research design was employed to test the hypothesized relationships between variables. To collect data; two different self-administered structured questionnaires were administered to airline employees and airline passengers. The questionnaires were also translated into Turkish through both forward and back translation. The data was collected through one month period from the middle of December 2012 to the middle of January 2013. At the end of data collection process, 449 employee questionnaires were identified as usable with 2 customer questionnaires for each employee. Therefore, 449 employee questionnaires and 898 passenger questionnaires were used for final data analysis.

\subsection{Data Aggregation}

This study employed conceptual integration of both employees and consumers in order to understand the effect of employee behaviors on customers (Gazzoli et al., 2010). Therefore, the unit of analysis in this study was the service employee. In order to match the responses of employees with respective customers, each flight attendant selected two passengers at the end of his or her flight to conduct the survey to passengers. Therefore, data were aggregated at the individual level by taking the average scores of customers for the flight attendant surveyed them (George \& Bettenhausen, 1990; Schneider \& Bowen, 1985). The data aggregation resulted in average of two passengers per flight attendant.

\subsection{Measurement}

Two different self-administered structured questionnaires were used to survey both employees and passengers. The structured-questionnaires to measure the constructs were designed based on the measurement scales adopted from previous studies. Participants were asked to assess their brand related attitudes and behaviors on a five-point Likert scale $(1=$ Strongly Disagree to $5=$ Strongly Agree $)$. The measures are explained in detail below;

Brand Citizenship Behaviors. For brand citizenship behaviors, participation (on the job) and positive word of mouth (off the job) were determined as extra-role branding efforts. This study used a four-item measure of brand citizenship behaviors to assess brand related behaviors of employees (Arnett et al., 2003; Bettencourt, 1997).

Consumer Brand Trust. The measure of brand trust is a four-item measure by Chaudhuri and Holbrook (2001). The items measuring the brand trust emphasized the consumers' expectations of organization as being dependable and reliable. The operationalization of brand trust was based on three facets of trust that are reliability, honesty, and safety. Therefore, four items in the scale aim to measure these three facets of the construct.

Consumer Brand Commitment. For this study, consumer brand commitment was considered emotional attachment of consumers to the brand. The study adopted the conceptualization of the previous study and used a 
three-item measure of consumer commitment to assess the relationship of consumers with the brand (Delgado-Ballester \& Munuera-Aleman., 2001).

\subsection{Data Analysis}

Once the data had been collected from respondents, it was screened for missing values to determine how to deal with them. This study used list wise deletion, which is the most common method to deal with missing values (Jackson et al., 2009). After screening the data for missing values, the analyses were conducted through two phases.

In the first phase, descriptive statistics for demographic profile of respondents and reliability analysis for constructs were performed by using SPSS 20.0. In the second phase, the hypothesized relationships were analyzed by structural equation modeling (SEM) through AMOS. SEM was chosen due to its advantage of testing series of relationships by modeling a regression structure for latent variables (Hair et al., 2005). Additionally, confirmatory factor analysis (CFA) was performed to test the measurement model for the relations between latent constructs and their respective observed variables.

\section{Results}

\subsection{Descriptive Statistics}

This study had two different samples of respondents that are flight attendants and passengers of the respective airline company. The sample of airline employees consisted of 449 respondents and the sample of airline customers consisted of 898 respondents in total.

For employees, males accounted for $28.3 \%$ (127) and females accounted for $71.7 \%$ (322). Majority of the employees were between the ages of 26-35 (63.7\%). The rest of the employees were between 18-25 (27.8\%) and 36-45 (8.5\%). Of the 449 employees, $40.3 \%$ (181) was single and $59.7 \%$ (268) was married. More than half of the respondents $(63.5 \%)$ held bachelor degree. The rest of the employees either had high school or pre-college degree accounting for $16.2 \%$ (73) and $20.3 \%$ (91) of the respondents respectively.

For 898 airline passengers, males accounted for 54.8\% (492) and females accounted for $45.2 \%$ (406) of the sample. Most of the passengers were over 35 years old. 30.2\% (283) of the respondents was 46 years old or above and 40.8\% (354) of them was between the ages of 36 and 45. Passengers between 18 and 25 accounted for $12.6 \%$ (113), and the rest between 26 and 35 accounted for $16.4 \%$ (148) of the sample. Regarding their marital status, most of the respondents (81.4\%) were married. While $15.6 \%$ (140) of the passengers were single, $3.0 \%$ (27) of them reported their marital status under the "other" category. For the education level of airline passengers, most of them hold bachelor degree that represents $72.7 \%$ (653) of the sample. $12.9 \%$ (116) of the respondents was the passengers with high school degree and $10.9 \%$ (94) of the respondents was the passengers having a graduate degree. Only $3.5 \%$ (33) of the sample had a pre-college degree. Regarding the nationality of the passengers using the airline company, most of them were from Turkey. While 646 of the 898 respondents were Turkish people, 252 of them had a different nationality.

\subsection{Measurement Model}

This study conducted confirmatory factor analysis to evaluate measurement model to assess the measurement quality of the scales (see Table 1). The results of the confirmatory factor analysis showed that the model achieved a good fit for the data (Hu \& Bentler, 1999). The model fit statistics for the measurement model were $\chi^{2}(124, \mathrm{~N}=449)=229.703, \mathrm{p}=0.00$; comparative fit index $(\mathrm{CFI})=.987$; Tucker-Lewis index $(\mathrm{TLI})=.986$; root mean square error of approximation $($ RMSEA $)=.029$; and root mean square residual $(\mathrm{RMR})=.030$.

After analyzing the fit for the measurement model, the internal consistency for each latent variable was evaluated by checking composite reliabilities (CR) and average variance extracted (AVE) for each construct. Based on the cut-off value of 0.70 , all composite reliability values of study constructs represented sufficient internal consistency, ranging from 0.69 to 0.90 (Fornell \& Larcker, 1981). All factor loadings of each variable were statistically significant through exceeding critical t-value of 2.576 at $p<.01$. On the other hand, the discriminant validity was assessed by comparing squared correlation of each pair of constructs with their average of AVEs (Fornell \& Larcker, 1981). As a result, both convergent and discriminant validity were evidenced for the constructs in the study. 
Table 1. Measurement model results for constructs

\begin{tabular}{llllll}
\hline & \multicolumn{5}{c}{ Cross-Construct Correlations } \\
\hline Measurement Scale & Mean & SD & 1 & 2 & 3 \\
\hline Brand Citizenship Behaviors & 3.33 & .39 & 1.00 & & \\
Consumer Brand Trust & 4.20 & .66 & .19 & & \\
Consumer Brand Commitment & 3.47 & .52 & .02 & .54 & 1.00 \\
Composite Reliability (CR) & & & .80 & .89 & .69 \\
Average Variance Extracted (AVE) & & & .51 & .67 & .52 \\
\hline
\end{tabular}

Table 2. Measurement model results for scale items

\begin{tabular}{lcc}
\hline Construct & Factor Load & Alpha \\
\hline Brand Citizenship Behaviors & AVE & .51 \\
In social situations, I often speak favorably about (company name) & .656 & .735 \\
I let my supervisor to know of ways how we can strengthen our brand image & .688 & .80 \\
I make constructive suggestions on how to improve our customers' brand experience & .639 \\
If I have a useful idea on how to improve our brand's performance, I share it with my & AVE.67 \\
supervisor & .835 \\
Consumer Brand Trust & .832 \\
I trust (company name) brand & .791 \\
I rely on (company name) brand & .816 \\
(Company name) is an honest brand & AVE .52 \\
(Company name) is a safe brand & .628 \\
ConsumerBrand Commitment & .651 \\
I consider myself to be loyal to the (company name) brand & .678 \\
To me, (company name) is clearly the best brand on the market & \\
I recommend flying with (company name) & \\
\hline
\end{tabular}

\subsection{Structural Model}

\subsubsection{Direct Effects of Brand Citizenship Behaviors on Consumer Brand Trust and Brand Commitment}

After conducting CFA and testing the measurement model, structural paths were analyzed by the structural model in order to test the hypothesized relationships in the study (see Table 3). As suggested by H1, brand citizenship behaviors of employees were found to positively affect brand trust of customers $(\beta=.43, p \leq .01)$. However, this study did not find a significant relation between brand citizenship behaviors and brand commitment of customers failing to support $\mathrm{H} 2(\beta=.06, \mathrm{p} \geq .05)$. On the other hand, it was found that consumer brand trust positively affected brand commitment of customers providing support for $\mathrm{H} 3(\beta=.35, \mathrm{p} \leq .01)$.

4.3.2 Moderating Effects of Nationality on the Link between Brand Citizenship Behaviors and Consumers' Relation with the Brand

The moderating effect of nationality on the relationship between employee brand citizenship behaviors and consumer brand trust as well as brand commitment was tested using the procedure suggested by Hayes et al. (2009). As suggested by H4, nationality moderates the link between employee brand citizenship behaviors and consumer brand trust. More specifically, the effect of brand citizenship behaviors of employees is found to be higher for Turkish passengers $(\beta=.63, \mathrm{p} \leq .01)$ compared to their effect on passengers from different nationalities $(\beta=.38, \mathrm{p} \leq .01)$. However, even the effect of brand citizenship behaviors of employees on customer brand commitment were also higher for Turkish passengers, this effect is not statistically significant for passengers from other nationalities failing to support H5. Therefore, this study did not provide support for the moderating effect of brand citizenship behaviors on brand commitment of customers. Accordingly, simple slope analyses were performed to assess any significant interaction (see Figure 2 and 3). While figure 2 confirms the moderating role of nationality on the relationship between brand citizenship behaviors and consumer brand trust, the interaction effect is not significant for consumer brand commitment. 


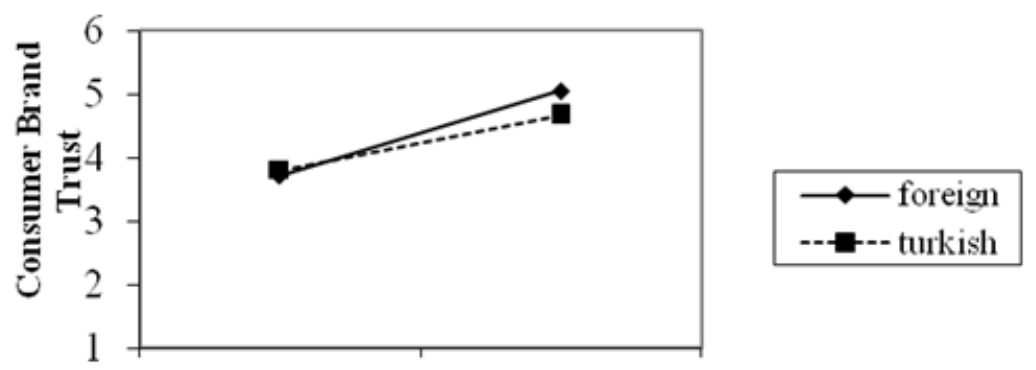

Low Brand Cit. Beh. High Brand Cit. Beh.

Figure 2. Moderating effect of nationality on the link between brand citizenship behaviors and consumer brand trust

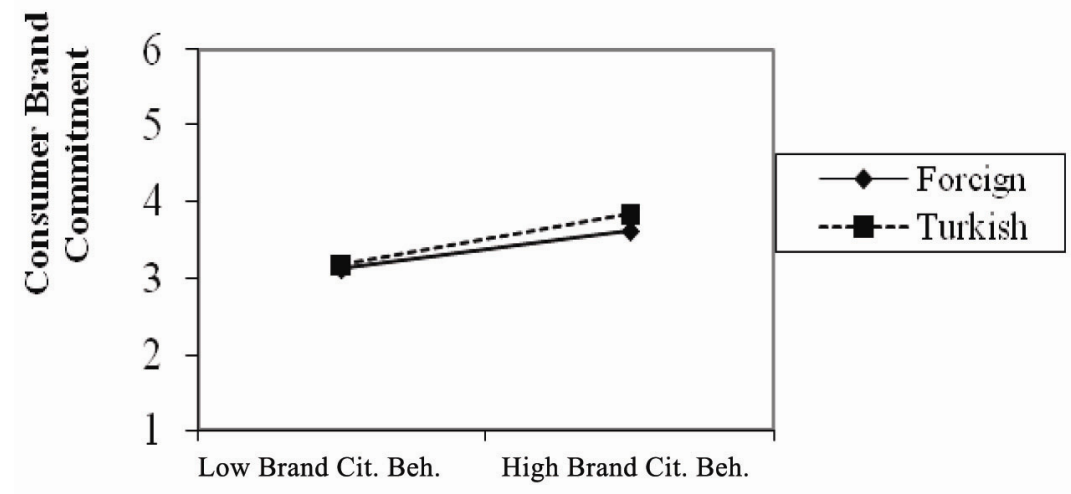

Figure 3. Moderating effect of nationality on the link between brand citizenship behaviors and consumer brand commitment

\section{Discussion and Conclusion}

With the recognition of importance of employees and consumers interaction for the brand success, the purpose of this study was to understand how employees' brand supporting behaviors affect consumers' relation with the brand as well as the role of consumer nationality on this relationship. A conceptual model was developed and tested to understand the moderating role of nationality on the link between employees' brand citizenship behaviors and consumers' relation with the service brand in terms of their trust and commitment.

Through a sample of airline employees and passengers, this research yields important results about how service employees may enhance consumers' relation with the brand through their behaviors. In line with the hypothesized relationships, the study found that brand citizenship behaviors positively affected brand trust for consumers. As employees adopted brand supporting behaviors, consumers' trust for the brand increased. This result was consistent with previous findings in the literature. When employees deliver the brand as it is promised, consumers have the confidence that the brand will perform as expected. Moreover they will build trust in the brand (Kimpakorn \& Tocquer, 2010; Papasolomou \& Vrontis, 2006). This finding was also somewhat similar with what has been found previously for airline travel. More specifically, passengers' satisfaction in air travel was found to significantly affect future behavioral intentions of airline travelers (Clemes et al., 2008; Ostrowski et al., 1993).

Additionally, the present study found that brand trust positively affected brand commitment of consumers. As consumers' trust increased, their commitment to the brand increased. These results also supported the previous findings regarding the role of trust and commitment in relationships (Dwyer et al., 1987; Keller, 2003; Morgan \& Hunt, 1994). Therefore, given the importance of employee behaviors based on these findings, it is reasonable to argue that employee brand related behaviors are important to enhance long term relationship with consumers. Particularly, those behaviors increase consumers brand trust, which in turn positively increases brand commitment. 
Lastly, for the moderating role of nationality, this study further suggested that passengers' nationality affects the link between employee behaviors and customer brand trust. The findings indicated that the effect of brand citizenship behaviors on brand trust was significantly higher for Turkish passengers. One reason for this finding might be the cultural congruency issue. Based on the cultural congruency theory, people are more likely to favor the service provider that is similar in terms of norms, values or language (Alden et al., 2009). Cultural similarity also helps to increase the confidence of consumers by providing an idea about the service quality (Kogut \& Singh, 1988). Therefore, it might be argued that people will have favorable attitudes for the service providers due to their national bonds. Another explanation for the difference between Turkish passengers and foreign passengers might be national stereotyping. Pizam and Sussman (1995) have found that employees in the tourism industry tend to perceive customers differently based on their emotions. Additionally, it has been found that national stereotyping affects employees' service behaviors (Cuddy et al., 2007). Specifically for the airline industry, airline employees were found to serve passengers based on their cognition and emotions. Moreover, they were found to show better service behaviors towards people from their own nationality (Kim \& Lee, 2009).

\section{Implications and Limitations}

\subsection{Theoretical Implications}

The present study tried to understand the moderating effect of consumer nationality on the link between employee brand citizenship behaviors and consumers' relation with the brand in the airline industry. Although, previous research has studied brand citizenship behaviors and their consequences, this research integrated both employees and customers into the same research model to understand how nationality affects consumers' relation with a company brand.

Given the importance of service employee behaviors' on consumers' evaluation of a service and a brand, this study confirmed that consumer nationality is also an important factor affecting how consumers become committed to a brand. In this present study, passengers who are from the same nationality with service employees were more likely to trust in the company brand and become committed to that brand. As a result, this study was first to analyze the effect of nationality on how consumers form their relation with a brand based on employee behaviors by conceptually integrating both employees and customers in the same research setting.

\subsection{Managerial Implications}

The findings of this study have also provided significant practical implications for airline industry in terms of managing the brand both for employees and for customers. First, the results showed that employee brand related behaviors affect how consumers form their relation with the brand. Therefore, airlines need to start branding from inside. First, they need to sell their brands to their own employees so that organizations can establish and enhance their passengers' brand relationship in the long term. If employees believe in the brand and live the brand, they can deliver the brand values as well as create the desired brand image in the minds of consumers through their brand supporting behaviors. The more employees consistently deliver the brand as it is expected, the more consumers feel trust and commitment regarding the brand. In conclusion, employees can enhance trust and commitment regarding the brand. Furthermore, they help forming long-term consumer relationship through their brand citizenship behaviors by strengthening the brand image.

Lastly, this study also confirmed that passengers' nationality is an important factor to explain their trust in and commitment to a corporate brand. Therefore, companies need to put more effort to manage their relationship with foreign customers who are from a different nationality. Foreign passengers are more likely to have less confidence in a foreign service provider as well as they usually look for similarities with the company providing the service. As a result, airline businesses need to pay attention to the needs of their foreign passengers, and they need to make them feel comfortable by providing a service that is similar to their needs and wants. With respect to the findings of this study, how airline companies would achieve this depends on the behaviors of their service employees. Companies need to provide a service environment that has more international standards and that is not too different what is expected by foreign consumers. If foreign people get a service that is similar to what they expect, they would have more confidence resulting in their trust and commitment.

\subsection{Limitations and Future Research}

Besides its theoretical and practical implications, this study has its own limitations. First of all, the study was conducted in a specific airline company. Therefore, external validity might be an issue for generalizability of the results to other airline companies. Second, convenience sampling used in this study might affect the representativeness of the sample for the population. Therefore, generalizing results and making inferences about the population poses a limitation and lowers the external validity of the present study. Third, employees were 
used to conduct the surveys to match each employee with their respective customers. Therefore, employees selected the participants based on their own will and decision. Forth, the participants asked to indicate their self-reported attitudes regarding scale items. However, it is difficult to guarantee that participants truly reflected their own attitudes and beliefs. Lastly, this study did not investigate all factors influencing consumers' relationship with the brand. For the customers, the level of involvement with the service (Delgado-Ballester \& Munuera-Aleman, 2001) and reputation of the brand (Selnes, 1993) might influence customers' trust and commitment.

Based on the findings of this study, future research might be conducted in the following areas. First of all, the proposed theoretical model might be applied in other airline companies to test whether hypothesized relations will hold true. In addition to the factors identified for the study, the other factors that might affect the brand-related behaviors and attitudes of consumers might be studied for their effect. As it is indicated in the limitations part, customers' level of involvement with the service or reputation of the brand might be further analyzed for their effect on customer brand relationship.

\section{References}

Alden, D. L., He, Y., \& Chen, Q. (2009). Service recommendations and customer evaluations in the international marketplace: Cultural and situational contingencies. Journal of Business Research, 63(1), 38-44. http://dx.doi.org/10.1016/j.jbusres.2009.01.009

Arnett, D. B., German, S. D., \& Hunt, S. D. (2003). The identity salience model of relationship marketing success: The case of nonprofit marketing. Journal of Marketing, 67(2), 89-106. http://dx.doi.org/10.1509/jmkg.67.2.89.18614

Arnold, M. J., \& Reynolds, K. E. (2009). Affect in retail shopping experiences: Exploring the role of mood regulation and regulatory focus. Journal of Retailing, 85(3), 308-320. http://dx.doi.org/10.1016/j.jretai.2009.05.004

Berry, L. L., \& Lampo, S. S. (2004). Branding labor-intensive services. Business Strategy Review, 15(1), 18-25.

Bettencourt, L. (1997). Customer voluntary performance: Customers as partners in service delivery. Journal of Retailing, 73(3), 383-406. http://dx.doi.org/10.1016/S0022-4359(97)90024-5

Bowen, D. E., Chase R. B., \& Cummings, T. G. (1990). Service management effectiveness. San Francisco, CA: Jossey-Bass Inc.

Burmann, C., \& Zeplin, S. (2005). Building brand commitment: A behavioral approach to internal brand management. Journal of Brand Management, 12(4), 279-300. http://dx.doi.org/10.1057/palgrave.bm.2540223

Burmann, C., Zeplin, S., \& Riley, N. (2009). Key determinants of internal brand management success: An exploratory empirical analysis. Journal of Brand Management, 16, 264-284. http://dx.doi.org/10.1057/bm.2008.6

Chaudhuri, A., \& Holbrook, M. B. (2001). The chain of effects from brand trust and brand affect to brand performance: The role of brand loyalty. Journal of Marketing, 65(2), 81-93. http://dx.doi.org/10.1509/jmkg.65.2.81.18255

Cleaver, C. (1999). Brands as the catalysts. Journal of Brand Management, 6(5), 309-312. http://dx.doi.org/10.1057/bm.1999.21

Clemes, M. D., Gan, C., Kao, T. H., \& Choong, M. (2008). An empirical analysis of customer satisfaction in international air travel. Innovative Marketing, 4, 50-62.

Cuddy, A. J. C., Fiske, S. T., \& Glick, P. (2007). The BIAS map: Behaviors from intergroup affect and stereotypes. Journal of Personality and Social Psychology, 92, 631-648. http://dx.doi.org/10.1037/0022-3514.92.4.631

De Chernatony, L., \& Segal-Horn, S. (2001). Building on services' characteristics to develop successful services brands. Journal of Marketing Management, 17, 645-669.

Delgado-Ballester, E., \& Munuera-Aleman, J. L. (2001). Brand trust in the context of consumer loyalty. European Journal of Marketing, 35(11/12), 1238-1258. http://dx.doi.org/10.1108/EUM0000000006475

Dowling, G. R. (1994). Corporate reputations: Strategies for developing the corporate brand. London: Kogan Page. 
Dwyer, F. R., Schurr, P. H., \& Oh, S. (1987). Developing Buyer-Seller Relationships. Journal of Marketing, 51(April), 11-27. http://dx.doi.org/10.2307/1251126

Fornell, C., \& Larcker, D. F. (1981). Evaluating structural equation models with unobservable variables and measurement error. Journal of Marketing Research, 18(1), 39-50. http://dx.doi.org/10.2307/3151312

Fournier, S. (1998). Consumers and their brands: Developing relationship theory in consumer research. Journal of Consumer Research, 24, 343-373. http://dx.doi.org/10.1086/209515

Frost, F. A., \& Kumar, M. (2001). Service quality between internal customers and internal suppliers in an international airline. International Journal of Quality and Reliability Management, 18(4), 371-386.

Gazzoli, G., Hancer, M., \& Park, Y. (2010). The role and effect of job satisfaction and empowerment on customers' perception of service quality: A study in the restaurant industry. Journal of Hospitality and Tourism Research, 34(1), 56-77. http://dx.doi.org/10.1177/1096348009344235

George, J. M., \& Bettenhausen, K. (1990). Understanding prosocial behavior, sales performance, and turnover: A group-level analysis in a service context. Journal of Applied Psychology, 75, 698-709. http://dx.doi.org/10.1037//0021-9010.75.6.698

Gilbert, D. C. (1996). Relationship marketing and airline loyalty schemes. Tourism Management, 17(8), 575-582. http://dx.doi.org/10.1016/S0261-5177(96)00078-7

Grönroos, C. (1990). Service management and marketing. Lexington, MA: Lexington Books.

Hair, J. F., Black, W., Babin, B., Anderson, R. E., \& Tatham, R. L. (2005). Multivariate data analysis. Upper Saddle River, NJ: Prentice Hall.

Hennig-Thurau, T., Groth, M., Paul, M., \& Gremler, D. D. (2006). Are all smiles created equal? How emotional contagion and emotional labor affect service relationships. Journal of Marketing, 70, 58-73. http://dx.doi.org/10.1509/jmkg.70.3.58

Hill, S. R., \& Tombs, A. (2011).The effect of accent of service employee on customer service evaluation. Managing Service Quality, 21(6), 649-660. http://dx.doi.org/10.1108/09604521111185637

Hu, L. T., \& Bentler, P. M. (1999). Cutoff criteria for fit indices in covariance structure analysis: Conventional criteria versus new alternatives. Structural Equation Modeling, 6, 1-55. http://dx.doi.org/10.1080/10705519909540118

Jackson, D. L., Gillaspy, J. A., \& Purc-Stephenson, R. (2009). Reporting practices in confirmatory factor analysis: An overview and some recommendations. Psychological Methods, 14, 6-23. http://dx.doi.org/10.1037/a0014694

Keller, K. L. (1993). Conceptualizing, measuring, and managing consumer-based brand equity. Journal of Marketing, 57, 1-22. http://dx.doi.org/10.2307/1252054

Keller, K. L. (2003). Strategic brand management: Building, measuring and managing brand equity. New Jersey: Prentice Hall.

Kim, W. G., Han, J., \& Lee, E. (2001). Effects of relationship marketing on repeat purchase and word of mouth. Journal of Hospitality and Tourism Research, 25(3), 272-288. http://dx.doi.org/10.1177/109634800102500303

Kim, Y. K., \& Lee, H. R. (2009). Airline employee's service behavior toward different nationalities. International Journal of Hospitality Management, 28(3), 454-465. http://dx.doi.org/10.1016/j.ijhm.2009.01.007

Kimpakorn, N., \& Tocquer, G. (2010). Service brand equity and employee brand commitment. Journal of Service Marketing, 24(5), 378-388. http://dx.doi.org/10.1108/08876041011060486

Kogut, B., \& Singh, H. (1988). The effect of national culture on the choice of entry mode. Journal of International Business Studies, 19(3), 411-432. http://dx.doi.org/10.1057/palgrave.jibs.8490394

Moorman, C., Deshpande, R., \& Zaltman, G. (1993). Factors affecting trust in market research relationships. Journal of Marketing, 57, 81-102. http://dx.doi.org/10.2307/1252059

Morgan, R. M., \& Hunt S. D. (1994). The commitment-trust theory of relationship marketing. Journal of Marketing, 58(3), 24-38. http://dx.doi.org/10.2307/1252308 
O’Loughlin, D., Szmigin, I., \& Turnbull, P. (2004). From relationships to experiences in retail financial services. The International Journal of Bank Marketing, 22, 522-539.

Ostrowski, P. L., O'Brien, T. V., \& Gordon, G. L. (1993). Service quality and customer loyalty in the commercial airline industry. Journal of Marketing, 22(2), 16-24. http://dx.doi.org/10.1177/004728759303200203

Ott, J. (1993). Airlines customer service rated "average" in survey. Aviation Week and Space Technology, 138(5), 31.

Papasolomou, I., \& Vrontis, D. (2006). Using internal marketing to ignite the corporate brand: The case of the UK retail bank industry. Journal of Brand Management, 14(1/2), 177-195. http://dx.doi.org/10.1057/palgrave.bm.2550059

Park J. W., Robertson, R., \& Wu, C. L. (2004). The effect of airline service quality of passengers' behavioral intentions: A Korean case study. Journal of Air Transport Management, 10, 435-439. http://dx.doi.org/10.1016/j.jairtraman.2004.06.001

Pizam, A., \& Sussman, S. (1995). Does nationality affect tourist behavior? Annals of Tourism Research, 22(2), 901-917. http://dx.doi.org/10.1016/0160-7383(95)00023-5

Punjaisri, K., \& Wilson, A. (2007). The role of internal branding in the delivery of employee brand promise. The Journal of Brand Management, 15(1), 57-70. http://dx.doi.org/10.1057/palgrave.bm.2550110

Punjaisri, K., Evanschitzky, H., \& Wilson, A. (2009). Internal branding: An enabler of employees' brand-supporting behaviors. Journal of Service Management, 20(2), 209-226. http://dx.doi.org/10.1108/09564230910952780

Schneider, B., \& Bowen, D. E. (1985). Employee and customer perceptions of service in banks: Replication and extension. Journal of Applied Psychology, 70, 423-433. http://dx.doi.org/10.1037//0021-9010.70.3.423

Selnes, F. (1993). An examination of the effect of product performance on brand reputation, satisfaction and loyalty. European Journal of Marketing, 27(9), 19-35.

Sirdeshmukh, D., Singh, J., \& Sabol, B. (2002). Customer trust, value, and loyalty in relational exchanges. Journal of Marketing, 66(1), 15-37.

Solomon, M. R., Surprenant, C., Czepiel, J. A., \& Gutman, E. G. (1985). A role theory perspective on dyadic interactions: The service encounter. Journal of Marketing, 49, 99-111. http://dx.doi.org/10.2307/1251180

Surprenant, C. F., \& Michael R. S. (1987). Predictability and personalization in the service encounter. Journal of Marketing, 51(April), 86-96. http://dx.doi.org/10.2307/1251131

Teng, C. C., \& Barrows, C. W. (2009). Service orientation: Antecedents, outcomes, and implications for hospitality research and practice. The Service Industries Journal, 29(10), 1413-1435.

Vella, P., Gountas, J., \& Walker, R. (2009). Employee perspectives of service quality in the supermarket sector. Journal of Services Marketing, 23(6), 407-421. http://dx.doi.org/10.1108/08876040910985870

Wallace, E., \& de Chernatony, L. (2008). Classifying, identifhttp://dx.doi.org/10.1080/02642060701842159 ying and managing the service brand saboteur. The Service Industries Journal, 28(1-2), 151-165.

Zeithaml V. A., Parasuraman, A., \& Berry, L. L. (1985). Problems and strategies in services marketing. Journal of Marketing, 49, 33-46. http://dx.doi.org/10.2307/1251563

Zins, A. H. (2001). Relative attitudes and commitment in customer loyalty models: Some experiences in the commercial airline industry. International Journal of Service Industry Management, 12(3-4), 269-297. http://dx.doi.org/10.1108/EUM0000000005521

\section{Copyrights}

Copyright for this article is retained by the author(s), with first publication rights granted to the journal.

This is an open-access article distributed under the terms and conditions of the Creative Commons Attribution license (http://creativecommons.org/licenses/by/3.0/). 